\title{
Serological And Haematological Responses To Experimental Fascioliasis And Treatment
}

\author{
Nour EI Din H. Sherif ${ }^{1}$, Ismail M. Shalaby ${ }^{1}$, Maha F. Soliman ${ }^{1}$, \\ Mohamed G. Hassan ${ }^{2}$ \\ ${ }^{1}$ Zoology Department, Faculty of Science, Suez Canal University, Ismailia, Egypt. \\ ${ }^{2}$ Parasitology Department, Faculty of Veterinary Medicine, Suez Canal University, \\ Ismailia, Egypt.
}

\begin{abstract}
:
This study was established to evaluate and monitor both the humoral and haematological responses to Fascioliasis and its treatment in rabbit model. Rabbits were orally inoculated with viable $F$. gigantica metacercariae and then divided into four groups. Infected rabbits were orally administered a single dose of Triclabendazole (TCBZ) $\left(10 \mathrm{mg} \mathrm{kg}^{-1}\right)$ at week 4,8 or 12 postinfection (pi), respectively. Antibody ( $\mathrm{Ab}$ ) response against infection was monitored using enzyme linked immunosorbant assay (ELISA). Total red blood cell counts (Rbcs), haemoglobin content $(\mathrm{Hb})$ and total and differential white blood cells (Wbcs) were also determined. Infected rabbits were found to produce $\mathrm{Ab}$ against excretory-secretory products (ESP) of adult flukes two weeks pi where ELISA enabled the early diagnosis of infection. Ab level reached to the peak at week 10 pi. In TCBZ-treated groups, the early Ab responses prior to treatments were similar to response of infected-untreated rabbits. But, after different treatment regimens, Ab levels showed a significant decreases that were depended mainly on both time and hence efficacy of the treatment. In addition, significant reductions in both Rbcs and $\mathrm{Hb}$ values accompanied with mild anemia were found among infected group at week 12 \&10 pi, respectively. TCBZ-treatment prevented the development of anaemia. Eosinophil numbers significantly increased starting from week 2 pi and peaking at week 4 or 6 pi in all groups. Hence, both eosniophilia and anaemia might be characteristic aspects for experimental fascioliasis.
\end{abstract}

Key words: Fascioliasis, Triclabendazole, enzyme linked immunosorbant assay, haematology

\section{Introduction}

Fascioliasis is a well-known parasitic disease because of its veterinary importance and the great losses it causes in livestock production (Mas-Coma \& Bargues 1997). Fascioliasis is also now an important human parasitic disease, with estimated ranging from 2.4 to 17 million people infected. (Mas-Coma et al., 1999). The number of cases of human fascioliasis reported in Egypt has increased drastically during the past years (Curtale et al., 2003).

At present, it is essential that methods to control the disease involve a chemotherapeutic strategy based on epidemiological knowledge. It is therefore necessary to develop methods for early diagnosis and to assay drugs which are effective against developmental stage of Fasciola (Martinez, et al., 1997). In this regards, large numbers of fasciolicides are available and used successfully allover the world. According to WHO (1998), Triclabendazole (TCBZ), a benzimidazole compound, has recently been registered in Egypt for the treatment of human fascioliasis. TCBZ has been used in veterinary practice for fascioliasis since 1983. However, time was not too far to recognized that TCBZ resistant liver flukes generated in buffaloes would be transmitted to other ruminant species as well as human (Sanyal, 1998).

Many literatures have been cited about the role of enzyme-linked immunosorbent assay (ELISA) in diagnostic purpose for fascioliasis (Levine et al., 1980, Cornelissen et al., 1992; Guobadia \& Fagbemi, 1996; Martinez et al., 1996). On the other hand, little is known about the various mechanisms of immunomodulation that occur either during fascioliasis or 
during disease treatment compared to informations available for other trematode infections like Schistosoma (Poitou et al., 1992; Martinez et al., 1997).

A broad spectrum of mammalian species especially herbivorous animals may serve as experimental hosts for the common liver flukes, Fasciola sp. Establishment of $F$. gigantica infection in the laboratory animals has been previously reported in mice (Yoshihara \& Suzuki, 1990), in rat (Yoshioka, 1991), in guinea pig (ELShaieb, 1995) and in rabbit (Abou-Basha et al., 1983; Desoky, 1985, Gupta \& Yadav, 1995; El-Bahy, 1997, Abdel-Rahman et al., 1997; El-Sayed, 1997; Helal et al., 2000; Abdel-Rahman \& Abdel-Megeed, 2004). In this regard, El-Bahy (1997) suggested that the best condition for production of mature $F$. gigantica worm in rabbit depends mainly on the dose of metacercariae and the general health conditions of the rabbit.

The present work was established for supporting the studies required for diagnosis and control of fascioliasis. The humoral and haematological responses to experimental fascioliasis alone and combined with the chemotherapy (TCBZ) in rabbit model were monitored.

\section{Material and methods \\ Animals \& Experimental Infection}

Twenty five rabbits (approximately, 2 $-2.5 \mathrm{~kg}$ ) were used for the establishment of $F$. gigantica infection. The rabbits were kept in clean metal cages and fed on balanced ration and water ad-libitum. The rabbits were healthy and free from parasites and infectious diseases as indicated by the absence of clinical signs and by performing blood analysis as well as the daily faecal examination for 10 days using the simple sedimentation technique (Faust, et al., 1939). Twenty rabbits were orally inoculated with $25 \pm 5$ viable $F$. gigantica metacercariae (age: 10-15 days) per animal; the viability of metacercariae were determined by the refractile appearance of the excretory granules (Boray, 1969) and the movement of juveniles within the cysts. The remaining five rabbits were served as control group (A).

\section{Treatment Regimens}

Infected rabbits were randomly allocated in four groups of five animals each (groups B, C, D \& E). Group B remained infected and did not receive treatment. At weeks 4, 8 and 12 post infection (pi), TCBZ was administered to groups $\mathrm{C}, \mathrm{D}$ and $\mathrm{E}$, respectively. TCBZ (FASINEX: CIBA-GEIGY, Switzerland) was orally administered as a single therapeutic dose of $10 \mathrm{mg} \mathrm{kg}^{-1}$ in distilled water. The dose was calculated according to Paget \& Barnes (1964).

\section{Blood Sampling:}

Blood samples were taken from the eye of all rabbits by using orbital sinus technique (Sanford, 1954) at weeks 0, 2, 4 $6,8,10,12,14$, and 16 pi. Blood samples were collected into tubes containing the anticoagulant (Ethylene - Diamine Tetra Acetate, EDTA) at the rate of $2 \mathrm{mg} / \mathrm{ml}$ of blood (Hawk et al., 1965) for haematological analysis and also into tubes without anticoagulant for preparation of sera and serological analysis. Obtained sera were stored at $-20^{\circ} \mathrm{c}$ till used in antibodies assay.

\section{F. gigantica Excretory - Secretory Product (ESP) (Antigen Preparation):}

ESP antigen was prepared according to Rivert Marrero et al. (1988). Flukes were collected from cattle bile ducts and washed several times in $0.01 \mathrm{M}$ phosphate buffered saline (PBS), $\mathrm{pH} 7.4$ and then incubated in PBS at $37^{\circ} \mathrm{C}$ for $3 \mathrm{hrs}$; one worm/ $5 \mathrm{ml}$ in PBS. The flukes were removed and the supernatant fluid (PBS + ESP) was centrifuged at $(12,000 \mathrm{rpm})$ for $1 \mathrm{hr}$ at $4^{\circ} \mathrm{c}$. The supernatant was separated and designated as ESP antigen. The protein content was determined by Biomeriux kit (laboratory reagent and instrument, France) according to Lowry et al. (1951). The antigen was aliquoted and stored at $-70{ }^{\circ} \mathrm{C}$ until used.

Enzyme Linked Immunosorbant Assay (ELISA):

Specific antibodies against $F$. gigantica ESP antigen were determined during infection and treatment using ELISA (Oldham, 1983). Microtiter plate (Nunc) was coated with $100 \mu \mathrm{l} \mathrm{ESP}$ antigen $(5 \mu \mathrm{g}$ 
protein $/ \mathrm{ml})$ in coating buffer $(0.05 \mathrm{M}$ carbonate buffer, $\mathrm{pH}$ 9.6) and incubated overnight at $4^{\circ} \mathrm{C}$. The plates were washed in PBS - Tween (PBS-T) - $20(0.05 \%)$ then $200 \mu \mathrm{l} / \mathrm{well}$ of blocking buffer, $0.1 \%$ bovine serum albumin, (BSA) was added and incubated for $1 \mathrm{hr}$ at $37^{\circ} \mathrm{C} .100 \mu \mathrm{l}$ of serum of all experimental groups diluted at 1:100 in PBS-T were added and incubated for $1 \mathrm{hr}$ at room temperature. After washing, $100 \mu 1 /$ well of the conjugate, Horseradish peroxidase conjugated goat anti rabbit IgG (whole molecule) (Sigma Immunochemicals) was added 1:2000 dilution in PBS- - T $0.05 \%$ (were added). The plates were incubated for $1 \mathrm{hr}$ at $37^{\circ} \mathrm{C}$. After washing, substrate, Ortho-phenylenediamidine (Sigma Immunochemicals) at $100 \mu 1 /$ well and incubated for 5 minutes at room temperature. The reaction was stopped by adding $100 \mu \mathrm{l} /$ well of $1 \mathrm{M} \mathrm{H}_{2} \mathrm{SO}_{4}$. The optical density (OD) was read using spectrophotometer (Titertek - multiscan, Mcc photometer \{Flow Lab, Mclean, Virginia \} at $492 \mathrm{~nm}$.

\section{Haematological parameters:}

The total red blood cells (Rbcs) and white blood cells (Wbcs) were counted per $\mu \mathrm{l}$ of blood by Neubauer double haemocytometer according to Miller \& Seward (1971). The blood haemoglobin $(\mathrm{Hb})$ and differential Wbcs counts were determined according to Jain (1986).

\section{Flukes Recovery and Drug Efficacy:}

At week 16 pi, all infected and treated rabbits were sacrificed and dissected. Flukes were recovered according to the method of Kendall et al. (1967) where livers and gall bladders were examined carefully for flukes; all recovered flukes were collected and counted. The anthelmintic efficacy of each drug was expressed as percentage reduction of the number of flukes in the treated groups when compared with the untreated control group, according to the following formula: (Mean number flukes in control group) - (Mean number of flukes in treated group) / (Mean number flukes in control group) X100.

\section{Histological examination}

Specimen of infected liver were removed out from scarified rabbits, fixed in $10 \%$ buffered formalin, embedded in paraffin, sectioned at $5 \mu \mathrm{m}$ thickness and stained with $\mathrm{H} \& \mathrm{E}$.

\section{Statistical analysis}

All data were conducted with the software packages Microsoft SPSS version 11.0, for statistical evaluation. Data were presented as means $\pm \mathrm{SE}$. A student's t-test and one way analysis of variance (ANOVA) were used.

\section{Results}

Monitoring of $\mathrm{Ab}$ response in all the experimental groups using ELISA is shown in Fig (1). In infected-untreated rabbits, group (B), Ab level began to rise above the levels of non-infected group (A) 2-week pi $(\mathrm{p}<0.01)$. After that there was a significant increase in Ab level, reaching to the peak at week 10 pi. Ab level showed a slight decrease at the end of the experiment (week $16 \mathrm{pi}$ ).

In TCBZ-treated groups (C-E), the early antibody response before treatment was similar to that of group B. The peak of $\mathrm{Ab}$ levels of group $\mathrm{C}$, treated at week $4 \mathrm{pi}$, was recorded at week 6 pi and after that the level remained nearly constant till week 12 pi followed by significant decrease at weeks 16 pi compared to level of group $B(p$ $<0.001)$. At this time $A b$ level was still above level of non-infected rabbits ( $\mathrm{p}<$ $0.001)$. Ab level reached to the peak at weeks $10 \& 12$ pi in groups $\mathrm{D} \& \mathrm{E}$, respectively. Ab levels showed a significant decrease $6 \& 2$ weeks post- treatment in groups $\mathrm{D}$ and $\mathrm{E}$, respectively. At week 16, $\mathrm{Ab}$ level of groups $\mathrm{D}$ and $\mathrm{E}$ was significantly lower than level of group B ( $p$ $<0.001$ ), but still exceed levels of preinfection $(\mathrm{P}<0.001)$. At week 16 pi, a significant difference in the Ab levels was found between groups $\mathrm{D}$ and $\mathrm{E}(\mathrm{P}<0.05)$.

Monitoring the changes in Rbcs, $\mathrm{Hb}$ in all groups throughout the time of experiment is shown in figures $(2 \& 3)$. Remarkable decrease in both Rbcs and $\mathrm{Hb}$ values (mild anaemia) of infected rabbits (group (B) were found at weeks $12 \& 10$ pi, respectively, when compared to noninfected group A $(p<0.01)$. This decrease extended to week $16 \mathrm{pi}$ (p <0.001). In TCBZ-treated groups $(\mathrm{C} \& \mathrm{D}), \mathrm{Rbcs} \& \mathrm{Hb}$ values were within the normal range. While 
in group E, a significant decrease below normal range was found starting from week 14 and 12 pi in Rbcs \& $\mathrm{Hb}$ values, respectively $(\mathrm{p}<0.01 ; \mathrm{p}<0.001)$.

Concerning the total Wbcs count, it was within the normal levels in all experimental groups. But, only the eosinophils showed a significant increase 2weeks pi, peaked at weeks 4 or 6 pi and followed by significant decrease in their number; although it was still above the normal levels (Fig. 4). No changes were recorded in the number of neutrophils, basophils, monocytes and lymphocytes; they were all around the normal values.

Regarding to TCBZ efficacy, our results showed that TCBZ was highly efficient in eliminating the flukes and its efficacy was dependent on time of administration. The efficacy was $93.75 \%$, $100 \% \& 100 \%$ for groups treated at weeks $4,8 \& 12$ pi, respectively. Figure (1) showed Fasciola gigantica worm resided in the bile ducts of an infected rabbit.

Table 1: Antibody Levels (Measured By ELISA) against $F$. gigantica ESP antigen during

\begin{tabular}{|c|c|c|c|c|c|}
\hline Weeks pi & Group A & Group B & Group C & Group D & Group E \\
\hline 0 & $0.13 \pm 0.03$ & $0.13 \pm 0.04$ & $0.4 \pm 0.03$ & $0.153 \pm 0.02$ & $0.131 \pm 0.03$ \\
\hline 2 & $0.16 \pm 0.03$ & $0.217 \pm 0.01$ & $0.238 \pm 0.02$ & $0.226 \pm 0.02$ & $0.23 \pm 0.03$ \\
\hline 4 & $0.14 \pm 0.03$ & $0.33 \pm 0.2$ & $0.33 \pm 0.02$ & $0.32 \pm 0.03$ & $0.32 \pm 0.03$ \\
\hline 6 & $0.13 \pm 0.04$ & $0.364 \pm 0.03$ & $0.364 \pm 0.03$ & $0.39 \pm 0.02$ & $0.372 \pm 0.02$ \\
\hline 8 & $0.14 \pm 0.04$ & $0.387 \pm 0.02$ & $0.39 \pm 0.02$ & $0.421 \pm 0.02$ & $0.366 \pm 0.02$ \\
\hline 10 & $0.153 \pm 0.02$ & $0.485 \pm 0.04$ & $0.47 \pm 0.03$ & $0.49 \pm 0.02$ & $0.36 \pm 0.04$ \\
\hline 12 & $0.13 \pm 0.04$ & $0.463 \pm 0.03$ & $0.484 \pm 0.04$ & $0.433 \pm 0.05$ & $0.0 .33 \pm 0.03$ \\
\hline 14 & $0.152 \pm 0.02$ & $0.412 \pm 0.2$ & $0.392 \pm 0.02$ & $0.254 \pm 0.01$ & $0.273 \pm 0.03$ \\
\hline 16 & $0.14 \pm 0.03$ & $0.385 \pm 0.02$ & $0.272 \pm 0.04$ & $0.215 \pm 0.02$ & $0.266 \pm 0.05$ \\
\hline
\end{tabular}

experimental fascioliasis and TCBZ-Treatment. Absorbance at $492 \mathbf{~ n m}$.

Results are given as mean \pm SE. A: Group A: Non-infected; B: Infected-untreated; C: Infectedtreated- 8 weeks pi; D: Infected-treated- 4 weeks pi; E: Infected-treated- 12 weeks pi.

\begin{tabular}{|c|c|c|c|c|c|}
\hline $\begin{array}{c}\text { Weeks } \\
\text { pi }\end{array}$ & Group A & Group B & Group C & Group D & Group E \\
\hline 0 & $4.53 \pm 0.2$ & $4.33 \pm 0.2$ & $4.6 \pm 0.9$ & $4.48 \pm 0.1$ & $4.97 \pm 0.3$ \\
\hline 2 & $4.35 \pm 0.2$ & $4.33 \pm 0.3$ & $4.45 \pm 0.2$ & $4.45 \pm 0.5$ & $4.47 \pm 0.3$ \\
\hline 4 & $4.35 \pm 0.3$ & $4.45 \pm 0.1$ & $4.45 \pm 0.5$ & $4.4 \pm 0.2$ & $4.7 \pm 0.1$ \\
\hline 6 & $4.25 \pm 0.3$ & $4.23 \pm 0.3$ & $4.2 \pm 0.2$ & $4.1 \pm 0.4$ & $4.25 \pm 0.2$ \\
\hline 8 & $4.05 \pm 0.3$ & $4.08 \pm 0.1$ & $4.35 \pm 0.3$ & $4.48 \pm 0.2$ & $4.38 \pm 0.3$ \\
\hline 10 & $3.73 \pm 0.2$ & $3.75 \pm 0.2$ & $4.33 \pm 0.3$ & $4.18 \pm 0.3$ & $4.38 \pm 0.2$ \\
\hline 12 & $3.6 \pm 0.2$ & $3.72 \pm 0.2$ & $3.88 \pm 0.3$ & $3.55 \pm 0.1$ & $4.4 .1 \pm 0.3$ \\
\hline 14 & $3.48 \pm 0.2$ & $3.83 \pm 0.3$ & $3.9 \pm 0.2$ & $3.4 \pm 0.3$ & $4.55 \pm 0.2$ \\
\hline 16 & $3.43 \pm 0.2$ & $3.75 \pm 0.1$ & $4.13 \pm 0.5$ & $3.15 \pm 0.3$ & $4.13 \pm 0.5$ \\
\hline
\end{tabular}

Table 2: Changes in RBCs $\left(\times 10^{6} / \mathrm{mm}^{3}\right)$ count during Fascioliasis and TCBZ- Treatment.

Results are given as mean \pm SE. A: Group A: Non-infected; B: Infected-untreated; C: Infectedtreated- 8 weeks pi; D: Infected-treated- 4 weeks pi; E: Infected-treated- 12 weeks pi. 
Table 3: Changes in HB (g \%) content during experimental Fascioliasis and TCBZTreatment.

\begin{tabular}{|c|c|c|c|c|c|}
\hline $\begin{array}{c}\text { Weeks } \\
\text { pi }\end{array}$ & Group A & Group B & Group C & Group D & Group E \\
\hline 0 & $10.78 \pm 0.8$ & $11 \pm 0.4$ & $10.65 \pm 0.5$ & $11.38 \pm 1.0$ & $10.9 \pm 0.1$ \\
\hline 2 & $10.75 \pm 0.4$ & $11.28 \pm 0.9$ & $10.55 \pm 0.6$ & $10.63 \pm 1.3$ & $10.8 \pm 0.5$ \\
\hline 4 & $10.75 \pm 0.6$ & $10.95 \pm 0.5$ & $10.68 \pm 0.7$ & $11.1 \pm 0.9$ & $10.93 \pm 0.9$ \\
\hline 6 & $10.35 \pm 0.7$ & $10.73 \pm 0.6$ & $10.98 \pm 0.9$ & $10.83 \pm 1.3$ & $10.78 \pm 0.9$ \\
\hline 8 & $9.88 \pm 0.4$ & $10.1 \pm 0.6$ & $10.53 \pm 0.4$ & $10.2 \pm 0.7$ & $10.95 \pm 1.0$ \\
\hline 10 & $9.38 \pm 0.2$ & $9.43 \pm 0.4$ & $10.3 \pm 0.4$ & $9.28 \pm 0.3$ & $10.6 \pm 0.7$ \\
\hline 12 & $8.25 \pm 0.24$ & $8.9 \pm 0.2$ & $9.95 \pm 0.4$ & $8.48 \pm 0.4$ & $10.85 \pm 0.5$ \\
\hline 14 & $8.45 \pm 0.2$ & $9.35 \pm 0.2$ & $10.1 \pm 0.4$ & $8.4 \pm 0.1$ & $10.28 \pm 0.5$ \\
\hline 16 & $8.88 \pm 0.3$ & $9.38 \pm 0.2$ & $10.4 \pm 0.8$ & $8.15 \pm 0.3$ & $11.1 \pm 0.83$ \\
\hline
\end{tabular}

Results are given as mean \pm SE. A: Group A: Non-infected; B: Infected-untreated; C: Infectedtreated- 8 weeks pi; D: Infected-treated- 4 weeks pi; E: Infected-treated- 12 weeks pi.

Table 4: Changes in number of eosinophils during experimental Fascioliasis and TCBZTreatment.

\begin{tabular}{|c|c|c|c|c|c|}
\hline $\begin{array}{c}\text { Weeks } \\
\text { pi }\end{array}$ & Group A & Group B & Group C & Group D & Group E \\
\hline 0 & $3 \pm 2.0$ & $3.1 \pm 1.2$ & $2.3 \pm 1.3$ & $2.5 \pm 1.2$ & $3.5 \pm 1.7$ \\
\hline 2 & $15.5 \pm 5.1$ & $9.5 \pm 3.1$ & $20 \pm 8$ & $17 \pm 6.1$ & $5 \pm 2.0$ \\
\hline 4 & $35.5 \pm 4.7$ & $25 \pm 7.8$ & $31 \pm 10.6$ & $33 \pm 7.7$ & $2.1 \pm 1.4$ \\
\hline 6 & $29 \pm 7.8$ & $19 \pm 6.5$ & $35 \pm 7.3$ & $24 \pm 8$ & $1.8 \pm 1.2$ \\
\hline 8 & $11.5 \pm 4.4$ & $18.5 \pm 7.5$ & $14.5 \pm 5.2$ & $10 \pm 3.9$ & $4.8 \pm 2.5$ \\
\hline 10 & $7.5 \pm 1.6$ & $8 \pm 1.7$ & $6.5 \pm 3$ & $8 \pm 4.8$ & $3.8 \pm 1.1$ \\
\hline 12 & $11.3 \pm 3.0$ & $10.5 \pm 3.3$ & $6.5 \pm 6.5$ & $6 \pm 2.1$ & $5.5 \pm 2.2$ \\
\hline 14 & $8.2 \pm 1.8$ & $6.5 \pm 3.5$ & $10.5 \pm 5.6$ & $13.5 \pm 6.4$ & $3.7 \pm 1.8$ \\
\hline 16 & $12 \pm 2.4$ & $9 \pm 3.7$ & $7.3 \pm 1.7$ & $9.5 \pm 1.1$ & $2.5 \pm 1.9$ \\
\hline
\end{tabular}

Results are given as mean \pm SE. A: Group A: Non-infected; B: Infected-untreated; C: Infectedtreated- 8 weeks pi; D: Infected-treated- 4 weeks pi; E: Infected-treated- 12 weeks pi.

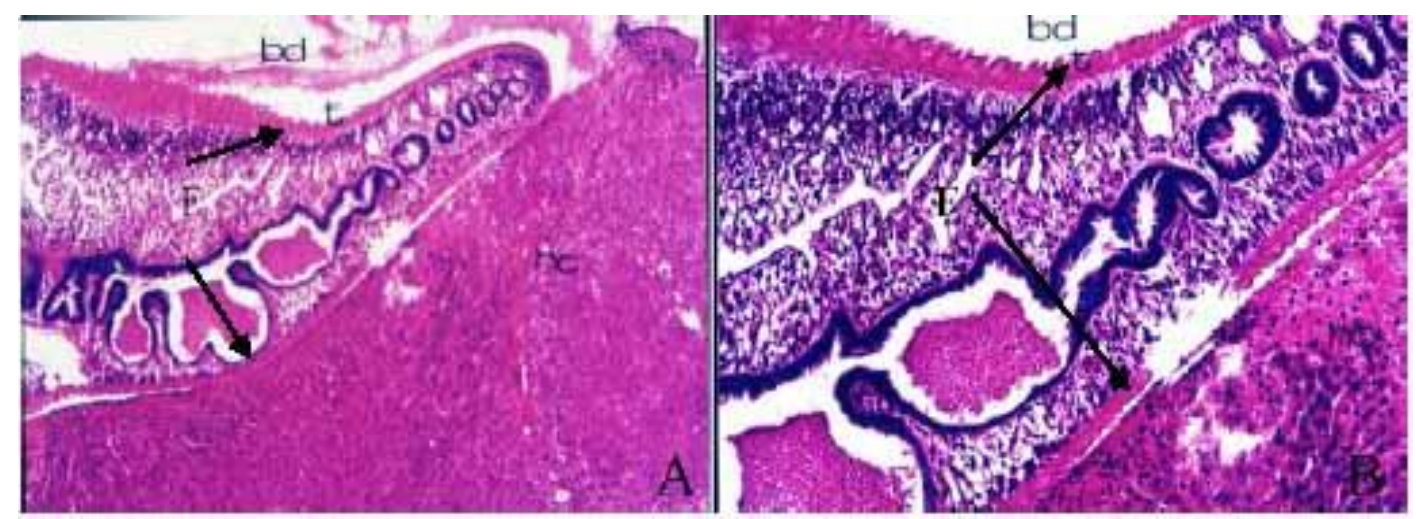

Fig 1 (A): Liver section of rabbit experimentally infected with $F$. gigantica showing the worm resided in the bile ducts. F: fluke; bd: bile duct; hc: hepatic cells; $t$ tegument of worm (x100). (B): enlarged liver section (x200). 


\section{Discussion}

Using direct ELISA method, $\mathrm{Ab}$ against ESP of adult $F$. gigantica was found early, two weeks pi, in sera of the experimentally infected rabbits where ELISA enabled the early diagnosis. This method, which has been used in other infections, showed satisfactory responses when employed in this study. Antibody level reached peak at week 10 pi. This antibody response was similar to that described for the primary infection with Fasciola sp.; in rat (Levine, et al., 1980), sheep (Cornelissen et al., 1992; Chauvin et al., 1995), cattle (Boulard et al., 1995) in goats (Martinez et al., 1996) and rabbit (El Bahy, 1997). On the other hand, the detection of antibodies by first week pi was recorded in rat (Yoshioka, 1991; Poitou, et al., 1992) and in sheep (Guodadia \& Fagbemi 1996) and by week 3 in rabbit (Santiago et al., 1986) and rat (Keegan \& Trudgett, 1992). Helal et al. (2001) found that $\mathrm{Ab}$ were detected in the sera of rabbits infected with $F$. gigantica at 6 week pi against adult and metacercarial antigen and at weeks 9-10 pi against ESP using precipitating test. Hence, these findings may confirm the advantage of using direct ELISA methods.

Antibody peak observed in this study at week $10 \mathrm{pi}$ indicated that there is a different $\mathrm{Ab}$ response at this late stage of infection compared to the early low response. In this regard, Poitou et al. (1992) pointed out that the antibody response is basically directed against antigen determinants of high molecular weight, present both in the juvenile tegument and in ESP structure in the adult. However, Hillyer (1979) found that ESP appeared more antigenic than tegument antigen using Eliza. This finding has been also supported by Chauvin et al. (1995), who suggested that the production of antibody appearing at the late stage of infection are related specifically to the sequential release of ESP by adult flukes in bile ducts.

In TCBZ-treated groups, the early antibody responses were similar to those of infected-untreated rabbits followed by significant decrease after treatment that was depended on both the time and efficacy of treatment. These findings are similar to those of Levine et al. (1980) in rat, Hanna, et al. (1982) in sheep, Fetterer, et al. (1985) in cattle and Martinez et al. (1997) in goats. Fetterer, et al. (1985) suggested that the reduced $\mathrm{Ab}$ response after treatment must be expected if drug treatment kills flukes while they are immature when antigen used in ELISA was prepared from adult flukes. In addition, it has been reported that when the early treatment failed to achieve total elimination of parasites, the post-peak decrease was marked after several weeks post-treatment, while, in goats in which treatment totally eliminated the parasite burden, $\mathrm{Ab}$ levels fell back very rapidly to negative values (Martinez et al., 1997). In contrary, our results showed that although there was a high significant drop in $\mathrm{Ab}$ levels at weeks $6 \& 2$ post treatment in groups D \& E, respectively, where there was total elimination of flukes, the levels did not reach to negative values at all. The reason of this variation in serological response between our study and the study of Martinez et al., (1997) may be related to the difference in immune response of the experimental animals used which could modify the mode of action of TCBZ treatment. For instance, TCBZ which was able to eliminate the ESP of flukes in goats may not be able to have the same effect in rabbit. However, these points need a further investigation.

The current study showed that experimental fascioliasis caused a mild anaemia starting from weeks $10-12$ pi in untreated-infected rabbits. Since at weeks 10 or 12 , usually the late immature or mature worms are found in bile ducts, the anemia might be directly related to the presence of worms in the ducts (Hawkins, 1984 and Martinez et al., 1997). In contrary, Haroun, et al. (1989) found anemic process in $F$. gigantica-infected goats at the start of infection that coincided with the migration of immature forms through the hepatic parenchyma. This study showed that TCBZ-treatment resulted in absence of anaemic processes when 
treatment was applied early in groups $\mathrm{C} \&$ D with $94 \%$ \& $100 \%$ fluke eradication rates, respectively. Only in group E, treated at week $12 \mathrm{pi}$, anaemia was found but the improvement may be expected in the followings weeks. However, many other factors might play a role in the anemic process during fascioliasis like size of the fluke burden (Hawkins, 1984) and species of animals (Waweru et al., 1999).

Eosinophilia, involved in hypersensitivity mechanisms and phagocytosis, is a feature of helminthes infestation, including Fasciola (Poitou et al., 1993 and Chauvin et al., 1995). Accordingly, a monophasic eosinophilia with one peak at week 4 or 6 was found in all infected and treated groups. Chauvin et al. (1995) described a biphasic eosinophilia with two peaks recorded from week 3-5 pi followed by drop and second increase from week 9-11 pi in $F$. hepatica infected sheep. In contrary, Martinez et al., (1997) reported that the leukocytes number were highly variable and no significant difference were detected between the non-infected, infected and treated goats experimentally infected with $F$. hepatica. However, we may suggest that both eosniophilia and anaemia might be characteristic aspects for experimental fascioliasis.

\section{References}

1. Abdel-Rahman, E.H. and AbdelMegeed, K. N. (2004): Fasciola gigantica: immuni-zation of rabbits with proteins isolated from coproantigen. J Egypt Soc Parasitol., 34(2): 631-642.

2. Abdel-Rahman, M.S., El Bahy MM. and EI-Bahy N.M. (1997): Testing the parasit-icidal efficacy of fental (nitazoxanide). Alex. J. Vet Science, 13(4): 447-458

3. Abou-Basha, L. M.; Elmagdoub, A. A.; Ebeid, S. A.; Toukhy,M.A.; Michael, A. I.; Hosny, K. M.; ElZoghby, S. M.; Faraq, H. F. and El-Sawy, M.F. (1983): Effect of bithionol on B-glucuronidase in serum and liver of rabbits infected with Fasciola gigantica. J. Egypt. Soc. Parasitol., 13(1): 231-238.

4. Boray, J. C. (1969): Experimental fasciol-iasis in Australia. Adv. Parasitol., 7: 95-210.
5. Boulard, C.; Carreras, F. and Van Gool, F. (1995): Evaluation of nitroxynil and closantel activity using ELISA and egg counts against Fasciola hepatica in experimentally and naturally infected cattle. Vet. Res., 26:249255.

6. Chauvin, A.; Bouvet, G. and Boulard, C. (1995): Humoral and cellular immune responses to Fasciola hepatica experimental primary and secondary infection in sheep. Int. J. Parasitol., 25(10):1227-1241.

7. Cornelissen, J.B.; De Leeuw, W. A. and Van der Heijden, P. j. (1992): Comparison of an indirect haemagglutination assay and an ELISA for diagnosing Fasciola hepatica in experimentally and naturally infected sheep. Vet. Quarterly, 14 (4): 152-156.

8. Curtale F, Abd El-Wahab Hassanein Y, El Wakeel A., MasComa S. and Montresore A. (2003): Distribution of human fascioliasis by age and gender among rural population in the Nile Delta, Egypt. J Trop Pediatr., 49(5):264-8.

9. Desoky, E.A (1985): Identification of antibodies against Fasciola gigantica in natural and experimental hosts using antigen from the development stages in snails. Ph.D. Thesis, Department of Parasitology, Faculty of Veterinary Medicine, Zagazig University.

10. El-Bahy, M. M. (1997): Rabbit as a model for experimental fasciollasis in Egypt. Alex. J. Vet. Sc., (13): 5

11. El-Sayed, M. H. (1997): Comparative studies on the effect of bithionol, praziq-uantel and triclabendazole in rabbit's fascioliasis. 1. Parasitological studies .J. Egypt. Soc. Parasitol., 27(1):13142.

12. El-Shaieb, A. F., (1995): Experimental pathologic studies on Fasciola gigantica and Trichinella spiralis in guinea pigs. Ph.D. Thesis, Department of Parasitology, Faculty of Veterinary Medicine, Zagazig University.

13. Faust, E. C.; Sawitz, W.; Tobile, J.; Pres, C. and Lincicim, D. R. (1939): Comp-arative efficiency of 
various techniques for the diagnosis of protozoa and helminthes in faeces. J. Parasitol., 25:241-262.

14. Fetterer, R. H.; Rew, R. S.; Gasbarre, L. C. and Ostlind, D. A. (1985): Prophylactic efficacy of clorsulon against Fasciola hepaticca in calves and sheep. Vet. Parasitol., 18: 21-27

15. Guobadia, E. E. and Fagbemi, B. O. (1996): Detection of circulating Fasciola gigantica antigen in experimental and natural infections of sheep with fascioliasis. Vet. Parasitol., 65 (1-2): 29-39.

16. Gupta, S. C. and Yadav, S. C. (1995): Antibody response of rabbit to enhanced doses of Fasciola gigantica experimental infection. J. Vet. Parasitol. : 73-77.

17. Hanna, R. E.; Hughes, D. L. and Taylor, S. M. (1982): Fasciola hepatica: antibody levels in sheep serum before and after treatment with antihelmintic. Res. Vet. Sci., 51(1): 328-332.

18. Haroun, E. M.; El-Sanhouri, A. A. and Gameel, A. A. (1989): Response of goats to repeated infections with Fasciola gigantica. Vet. Parasitol., 30(4): 287-296.

19. Hawk, P. B., Oser, B. L. and Summerson, W. (1965): Hawk's physilogical chemistry. $14^{\text {th }}$ London. J. and Aohurchill. pp. 33.

20. Hawkins, C. D. (1984): The use of haemoglobin, packed cell volume and serum sorbitol dehydrogenase as indicators of the development of fascioliasis in sheep. Vet Parasitol., 15:125-133.

21. Helal, I. B., Moustafa, H. E. and Nabila M. M. (2000): Hostparasite interaction in rabbit fascioliasis. I. C. B. S., 1(2) :595612.

22. Hillyer, G. V.(1980): Isolation of Fasciola hepatica tegument antigens. J. Clinc. Microbiol., 12(5): 695-699.

23. Jain, N. C. (1986): Veterinary haematology $4^{\text {th }}$, Lea and Febiger, Philadelphia, USA

24. Keegan, P. S. and Trudgett, A. (1992): Fasciola hepatica in the rat: immune respo-nses associated with the development of resistance to infection. Parasite Immunol., 14: 657-669.
25. Kendall, S. B.; Hebert, N. J.; Parfitt, J. W. and Peirce, M. A. (1967): Resistance to reinfection with Fasciola hepatica in rabbits. Exp. Parasitol., 20: 242-247.

26. Levine, D. M.; Hillyer, G. V. and Flores, S. I. (1980): Comparison of counterelectro-phoresis, the enzyme-linked immunosorbent assay, and Kato fecal examination for the diagnosis of Fascioliasis in infected mice and rabbits. Am. J. Am. J. Trop. Med. Hyg., 29(4):602608.

27. Lowry, O. H., Rosenbrough, N. J., farr, A. L. and Randall, R. J. (1951): Protein measurement with folin-phenol reagent. J. Biol. Chem., 193: 265-275.

28. Martinez, A.: Martinez-Cruz, M. S.; Martinez, F. J.; Gutierrez, P. N. and Hernandez, S. (1996): Detection of antibodies to Fasciola hepatica excretory-secretory antigens in experimentally infected goats by enzyme linked immunosorbent assay. Vet. Parasitol., 62:247-252.

29. Martinez A., Martinez-Moreno F. J., Acosta I.,Gutierrez P. N., Becerra C. and Hernandez S.(1997): Humoral and cellular immune responses to experimental Fasciola hepatica infections in goats. Parasitol. Res., 83(7): 680686.

30. Mas-Coma S. and Bargues M.D, (1997): Human liver flukes: a review. Res Rev Parasitol., 57: 145-218

31. Mas-Coma M. S., Esteban J. G. and Bargues M. D. (1999): Epidemiology of human fascioliasis: a review and proposed new classification. Bull World Health Organ; 77(4):340-346.

32. Miller, S. E. and Seward, J. M. (1971): Textbook of clinical pathology. $8^{\text {th }} \mathrm{Ed}$, The willians and Wilking Company, Baltimore. pp. 22.

33. Oldham, G. (1983): Antibodies o Fasciola hepatica antigens during experimental infections in cattle measured by ELISA. Vet. Parasitol., 13: 151-158.

34. Paget, G. E. and Barnes, J. M. (1964): Evaluation of drug activities. Vol.1, Academic Press. 
35. Poitou, I.; Baeza, E. and Boulard, C. (1992): Humoral and cellular immune responses in rats during a primary infestation with Fasciola hepatica. Vet. Parasitol., 45(12):59-71.

36. Poitou, I.; Baeza, E. and Boulard, C. (1993): Kinetic responses of parasite-specific antibody isotypes, blood leucocytes pattern and lymphocyte subsets in rats during primary infestation with Fasciola hepatica. Vet. Parastiol., 49: 179190.

37. Rivert Marrero, C. A.; Santiago, N. and Hiyller, G. V. (1988): Evaluation oh immuneodiagnostic antigens in the excretory-secretory products of Fasciola hepatica. J. Parasitol., 74(4):646-652.

38. Sanford, H. S. (1954): Method for obtaining venous blood from the orbital sinus of the rat or mouse. Science, 119: 100.

39. Santiago, N.; Hillyer, G. V.; Garcia-Rosa, M. and Morales, $M$. H. (1986): Identif-ication of functional Fasciola hepatica antigens in experimental infections in rabb-its. Am. J. Trop. Med.Hyg., 35(1):135-140.

40. Sanyal, P.K. (1998): Pharmacokinetics behavior of Triclabendazole in domestic ruminants following single and divided dose adinistration. J. Vet. Parasitol., 12(2): 89-93.

41. Waweru, J. G.; Kanyari, P. W.; Mwangi, D. M.; Ngatia, T. A. and Nansen, P. (1999): Comparative parasitological and haematological changes in two breeds of sheep infected with Fasciola gigantica. Trop.Anim.Health.Prod., 31(6):363-372.

42. WHO (1998): Triclabendazole and fascioliasis - a new drug to combat an age-old disease. Fact sheet no. 191. Geneva.

43. Yoshihara, S. and Suzuki, K. (1990): Antigens and antibodies in the ascitic fluid of mice infected with Fasciola gigantica. Vet. Parasitol., 35: 175-178.

44. Yoshioka, Y.

(1991): Immunodiagnostic and pathological studies on experimental fascioliasis in rats. Jpn. Nara. Med. Ass., 42:587-603.

\section{استجابات سيرولوجية و دموية على الإصابة بالفاشيولاو علاجها}

$$
\begin{aligned}
& \text { نور الاين شريف -إسماعيل شلبى - مها سليمان - محمد جمال حسن } \\
& \text { قسم علم الحيوان- كلية العلوم - جامعة قناة السويس- الإسماعيلية - جمهورية مصر } 1 \text { العربية } \\
& 2 \text { قسم الطفيليات ـ كلية الطب البيطرى- جامعة قناة السويس- الإسماعيلية - } \\
& \text { جمهورية مصر العربية }
\end{aligned}
$$

فى هذه الدراسـت تمـت مر اقبـة وتقيّيم الإستجابات المناعيـة و الدمويـة للإصـابة بالفاثيو لا معملياً و علاجها. تمـت إصـابة الأرانب بميتاسـركاريات فاثنيو لا جايجانتيكا عن طريق الفم وبعد ذلك تثـعبت الأر انب المصسابة إلى أربع مجمو عـات. تم علاج 3 مجمو عات من الأر انب المصابة بجر عة و احدة عن طريق الفم من عقار تريكلابندازول

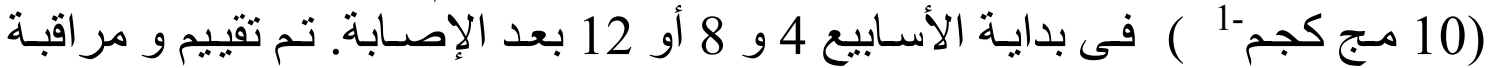
الإستجابة المناعية ضد الإصـابة بالفشيو لا باستخدام المو اد الإخر اجية للدوده البالغة عن الإسبه

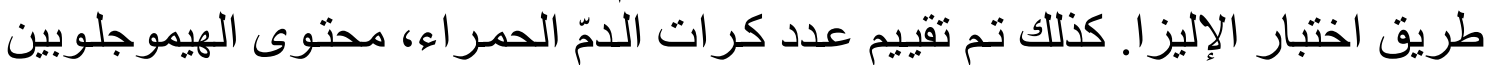

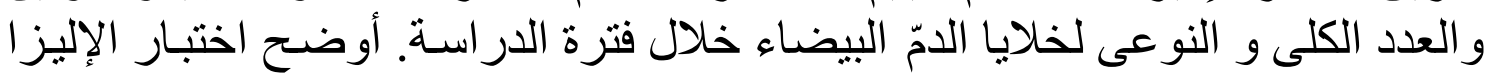
وجود اجسـام مناعيـة فى الأرانب المصـابة عند الأسبوع الثانى من العدوى المعملية 


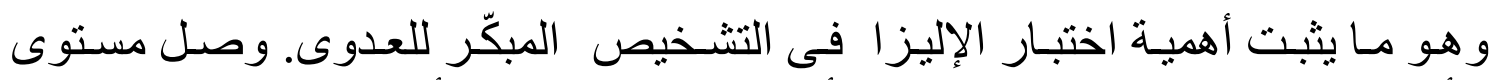

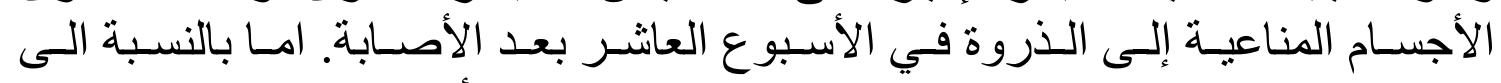

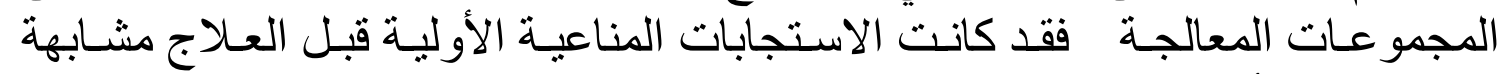

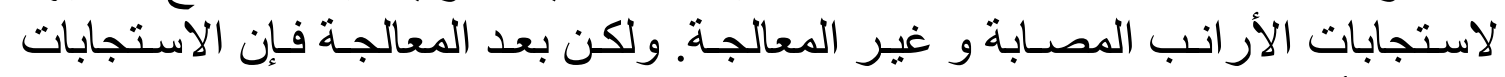

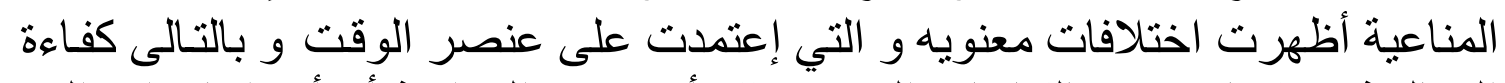

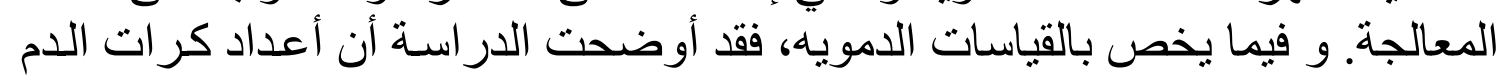

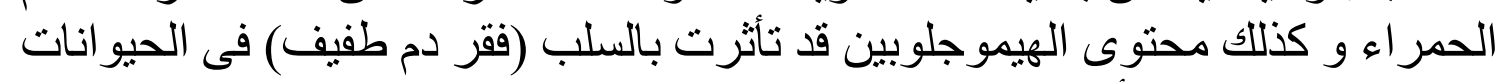

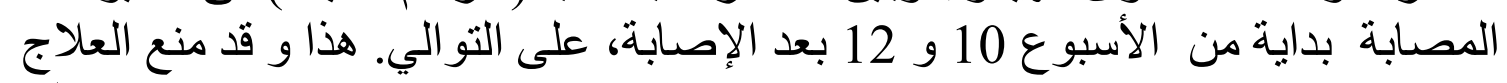

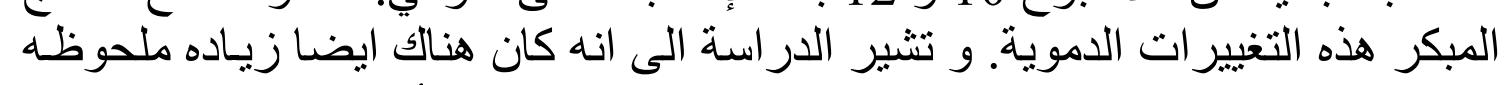

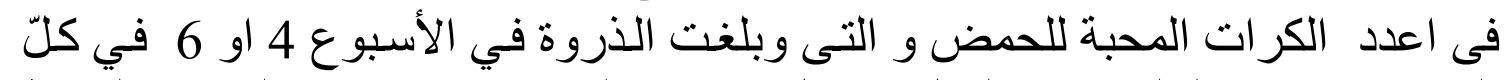

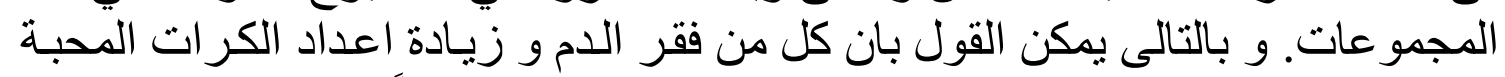

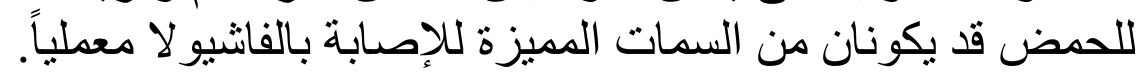

